\title{
Elevated Glucose Alters Eicosanoid Release from Porcine Aortic Endothelial Cells
}

\author{
Michael L. Brown, Joseph A. Jakubowski, Lynn L. Leventis, and Daniel Deykin \\ Department of Medicine and Biochemistry, Boston University School of Medicine, and the Boston Veterans Administration Medical \\ Center, Boston, Massachusetts 02130
}

\begin{abstract}
Cultured porcine aortic endothelial cells were conditioned through two passages to mimic euglycemic and hyperglycemic conditions (5.2 mM, normal glucose; $15.6 \mathrm{mM}$, elevated glucose). After incubation with $1 \mu \mathrm{M}\left[{ }^{14} \mathrm{C}\right]$ arachidonic acid for 24 $h$, the cells were stimulated with $1 \mu \mathrm{MA23187}$ for times up to 30 min. Uptake of $\left[{ }^{14} \mathrm{C}\right]$ arachidonic acid and its distribution among cell lipids were unaffected by the increased glucose concentration. The release of eicosanoids from labeled cells and unlabeled cells was measured by reverse-phase HPLC and by RIA, respectively. Compared with cells stimulated in the presence of normal glucose concentrations, cells stimulated in the presence of elevated glucose released $62.6 \%$ less free $\left[{ }^{14} \mathrm{C}\right.$ arachidonic acid, but released $129 \%$ more ${ }^{14} \mathrm{C}$-labeled 15 -hydroxyeicosatetraenoic acid (HETE). Increased release of 15HETE in the presence of elevated glucose in response to A23187, bradykinin, and thrombin was confirmed by RIA. A similar increase in 5-HETE release was observed by RIA after A23187 treatment. The release of both radiolabeled and unlabeled prostanoids was equal at both glucose concentrations. The data indicate that glucose may play an important role in the regulation of release and metabolism of arachidonic acid after agonist stimulation. In the presence of elevated glucose concentrations, such as those associated with diabetes mellitus, the extent and pattern of eicosanoid release from endothelial cells is markedly altered.
\end{abstract}

\section{Introduction}

Altered eicosanoid production is among the many factors implicated in the pathogenesis of diabetic vascular disease. Both elevated platelet $\mathrm{TXA}_{2}$ and diminished vascular prostacyclin $\left(\mathrm{PGI}_{2}\right)$ synthesis have been reported $(1,2)$. In addition to cyclooxygenase-derived products, both platelets and endothelial cells produce hydroxyeicosatetraenoic acids (HETEs), ${ }^{1}$ metabolized by the lipoxygenase pathway of arachidonic acid oxygenation (3-7). Several studies have suggested that these HETEs may influence the production of $\mathrm{PGI}_{2}(7,8)$. Glucose

Presented in part at the Annual Meeting of the American Association of Physicians, Washington, DC, May 1988.

Address reprint requests to Dr. M. L. Brown, Department of Hemostasis Research, Boston Veterans Administration Medical Center, 150 South Huntington Avenue, Boston, MA 02130. Dr. Jakubowski's present address is Department of Cardiovascular Pharmacology, Eli Lilly and Co., Indianapolis, IN 46285.

Received for publication 7 April 1987 and in revised form 1 July 1988.

1. Abbreviations used in this paper: HETE, hydroxyeicosatetraenoic acid.

The Journal of Clinical Investigation, Inc.

Volume 82, December 1988, 2136-2141 has been shown to enhance the production of 12-HETE in pancreatic islet cells $(9,10)$.

Our present studies were undertaken to examine the effect of glucose on eicosanoid production by cultured porcine aortic endothelial cells. Eicosanoid biosynthesis was induced by both receptor-mediated (bradykinin and thrombin) and receptorindependent (ionophore A23187) agonists. Our data demonstrate that, regardless of the stimulus used, an increased glucose concentration strikingly augments the production of 15HETE but diminishes the release of free arachidonic acid.

\section{Methods}

Culture and conditioning of porcine aortic endothelial cells. Porcine aortic endothelial cells were isolated and cultured by methods previously described $(11,12)$. Cells were cultured in DME containing $10 \%$ FCS (Biofluids, Rockville, MD) and 1,000 $\mathrm{U} / \mathrm{ml}$ of penicillin $\mathrm{G}$ and $100 \mu \mathrm{g} / \mathrm{ml}$ of streptomycin. This complete medium was replaced every $2 \mathrm{~d}$ and used throughout subsequent cultures unless otherwise stated. At confluence, the aortic endothelial cells appeared as typical "cobblestone" patterned monolayers and stained positively for the acetylated low density lipoprotein receptor and the Factor VIII-related antigen.

Cells were subcultured by exposure to $0.05 \%$ trypsin (Type I; Sigma Chemical Co., St. Louis, MO), 0.02\% EDTA in $\mathrm{Ca}^{2+}, \mathrm{Mg}^{2+}$-free HBSS, $\mathrm{pH} 7.4$, using a split ratio of 1:4. After the second to third passage, cells were divided into two groups and grown through two passages under conditions of normal glucose ( $5.2 \mathrm{mM} ; \mathrm{G}-\mathrm{N}$ cells) and elevated glucose (15.6 mM; G-E cells). All media used during subsequent labeling and stimulation contained the above concentrations of glucose. All glucose supplements were conducted by the addition of $\beta$-D(+)-glucose (Sigma Chemical Co.) to the culture medium. All experiments utilized cultured cell monolayers that were confluent.

Cell proliferation. After the first passage under G-N or G-E conditions, confluent cultures were trypsinized and subcultured at a split ratio of 1:4 into their respective culture conditions. Daily cell counts were performed, after dispersion with trypsin, using a hemocytometer. Cell doubling times were obtained from the linear portion of the curve obtained by plotting the log cell number against the number of hours in culture.

Protein determination. Total protein was determined by a protein assay system according to the manufacturer's instructions (Bio-Rad Laboratories, Richmond, CA) using BSA as the standard. Cellular material used for protein determinations was obtained as follows. Confluent cell cultures in 100-mm dishes were washed three times with $5 \mathrm{ml}$ of $\mathrm{Ca}^{2+}, \mathrm{Mg}^{2+}$-free $\mathrm{HBSS}$ and digested directly with $2.5 \mathrm{ml}$ of $1 \mathrm{M}$ $\mathrm{NaOH}$ overnight at ambient temperature. The digest was neutralized with $2.5 \mathrm{ml}$ of $1 \mathrm{M} \mathrm{HCl}$ before assay. In other experiments, isolated cell suspensions were obtained by dispersion with $0.02 \%$ EDTA and digested and assayed as above.

Labeling with $\left[{ }^{14} \mathrm{C}\right]$ arachidonic acid and stimulation with A23187. Confluent cultures were rinsed twice with DME. A final concentration of $1 \mu \mathrm{M}\left[1-{ }^{14} \mathrm{C}\right]$ arachidonic acid (DuPont New England Nuclear, Boston, MA; $54.9 \mathrm{mCi} / \mathrm{mmol}$ ) complexed to $1 \mu \mathrm{M} \mathrm{BSA}$ (essentially fatty acid free; Sigma) in $10 \mathrm{ml}$ of complete medium was added to the plates and incubated for $24 \mathrm{~h}$. After $24 \mathrm{~h}$, the cells were rinsed twice with DME and reincubated with $10 \mathrm{ml}$ of this medium containing 0.05 $\mathrm{mg} / \mathrm{ml} \mathrm{BSA}$. The plates were allowed to equilibrate in the incubator for $2 \mathrm{~h}$ before further experimentation. 
$\left[{ }^{14} \mathrm{C}\right]$ Arachidonic acid-labeled cells were incubated with $1 \mu \mathrm{M}$ A23187 (Sigma) or an equivalent concentration $(0.02 \%)$ of dimethyl sulfoxide (vehicle) for varying times up to $30 \mathrm{~min}$. At completion of the time interval the medium was aspirated, acidified to $\mathrm{pH} 3.5$ with $1 \mathrm{M}$ formic acid, and extracted three times with equal volumes of ethyl acetate.

Resolution of ${ }^{14} \mathrm{C}$-labeled eicosanoids by HPLC. The ethyl acetate extracts were dried under nitrogen and resuspended in $200 \mu \mathrm{l}$ of acetonitrile. An aliquot of the extract was injected into a high performance liquid chromatograph (Waters Associates, Milford, MA) fitted with an Altex Ultrasphere ODS reverse phase column $(5 \mu \mathrm{m}, 250 \times 4.6 \mathrm{~mm})$. Elution was monitored by absorption at $192.5 \mathrm{~nm}$ and by the ${ }^{14} \mathrm{C}$ radioactivity in the collected fractions.

Eicosanoids were eluted at a flow rate of $1.5 \mathrm{ml} / \mathrm{min}$ using a threestep solvent system of acetonitrile/0.017 $\mathrm{M} \mathrm{H}_{3} \mathrm{PO}_{4}, \mathrm{pH} 3.3$ as follows: (step 1) 32:68; (step 2) 50:50; and (step 3) 75:25, for 30, 20, and $26 \mathrm{~min}$, respectively. Authentic prostaglandin (PG), leukotriene (LT), and HETE standards (Cayman Chemicals, Ann Arbor, MI) were used as references. 1-min fractions were collected and ${ }^{14} \mathrm{C}$ radioactivity was assessed by liquid scintillation counting. Radiochromatographic peaks were matched with ultraviolet spectrophotometric peaks for identification. Column recovery and extraction efficiency both exceeded $95 \%$.

$R I A$ of eicosanoids. In separate experiments 6-keto-PGF ${ }_{1 \alpha}, 5-$ HETE, and 15-HETE were measured by RIA following stimulation with $1 \mu \mathrm{M}$ A23187 (as above), $1 \mu \mathrm{M}$ bradykinin, or $2.5 \mathrm{U} / \mathrm{ml}$ human thrombin (both from Sigma). The experiments were otherwise identical to the procedures described above except that exogenous arachidonic acid was not added to the cell cultures. At various time points after the addition of agonist the medium was aspirated, transferred into plastic tubes, acidified, and immediately frozen for subsequent RIA.

Antisera against 6-keto-PGF ${ }_{1 \alpha}$ (Dr. Lawrence Levine, Brandeis University, Waltham, MA), 5-HETE, and 15-HETE (Advanced Magnetics, Boston, MA) demonstrated $<5 \%$ cross-reactivity with other major eicosanoids tested. Standard curves and dilutions were performed in DME containing $0.05 \%$ BSA. Standard curves performed with the addition of glucose $(15.6 \mathrm{mM})$ were identical to those performed in normal glucose. Other assay conditions were as previously described (13).

\section{Results}

In preliminary experiments we observed that increasing the concentration of glucose in the culture medium had no effect on the net uptake of $\left[{ }^{14} \mathrm{C}\right]$ arachidonic acid $\left(1,117 \pm 41 \times 10^{3}\right.$ cpm into G-N cells and $1,117 \pm 49 \times 10^{3} \mathrm{cpm}$ into G-E cells at $24 \mathrm{~h}$, mean $\pm \mathrm{SE}, n=3$ ) nor its distribution in cellular phospholipids. Cell morphology and growth $\left(\sim 6.5 \times 10^{6}\right.$ cells/100 $\mathrm{mm}$ dish at confluence) were also unaffected by the elevated glucose. Cell doubling times were identical $(31.1 \pm 1.3 \mathrm{~h}$ under G-N conditions and $31.1 \pm 1.2 \mathrm{~h}$ under G-E conditions, mean $\pm \mathrm{SE}, n=3$ ). Total cellular protein was likewise unaltered by glucose treatment $\left(171 \pm 6.0 \mu \mathrm{g} / 10^{6}\right.$ cells, G-N and $167 \pm 6.3$ $\mu \mathrm{g} / 10^{6}$ cells, G-E; mean $\pm \mathrm{SE}, n=5$ ). Identical data were obtained regardless of whether the intact monolayer was digested or if dispersed cells were used. The distribution of ${ }^{14} \mathrm{C}$ radioactivity among the major lipids was as follows. For G-N cells: neutral lipid, $6.7 \pm 0.9 \%$; phosphatidylethanolamine, $45.0 \pm 2.4 \%$; phosphatidylinositol, $24.7 \pm 1.4 \%$; phosphatidylcholine, $22.0 \pm 1.5 \%$ and phosphatidylserine, $1.5 \pm 0.3 \%$. For G-E cells: neutral lipid, 7.7 $\pm 1.3 \%$; phosphatidylethanolamine $43.4 \pm 3.2 \%$; phosphatidylinositol, $23.5 \pm 2.7 \%$; phosphatidylcholine, $24.3 \pm 1.4 \%$ and phosphatidylserine, $1.1 \pm 0.6 \%$. Cellular lipids were extracted and analysed as previously described (12). The present data are in good agreement with these previous results. Despite the lack of effect of glucose on the total cellular uptake and distribution of $\left[{ }^{14} \mathrm{C}\right]$ arachidonic acid, increased glucose exerted a marked effect on the ionophore-induced release of ${ }^{14} \mathrm{C}$ radioactivity. Total release of ${ }^{14} \mathrm{C}$ radioactivity, expressed as percentage of total radioactivity incorporated, was the same at both glucose concentrations for the initial $10 \mathrm{~min}$ after ionophore stimulation: $16.6 \pm 2.2 \%, \mathrm{G}-\mathrm{N}$ cells; $16.9 \pm 2.7 \%$, G-E cells (mean $\pm \mathrm{SE}$, six experiments performed in duplicate; $5 \times 10^{5}$ cells $/ 32-\mathrm{mm}$ plate). In G-N cells, net release of radioactivity doubled during the next $20 \mathrm{~min}$ $(35.4 \pm 1.3 \%$ release at $30 \mathrm{~min})$, but in cells stimulated in the presence of increased glucose there was no further net release of radioactivity $(16.9 \pm 1.3 \%$ release at $30 \mathrm{~min})$. In parallel experiments, the release of 6-keto-PGF ${ }_{1 \alpha}$ as measured by RIA was similar in G-N and G-E conditions, both at $10 \mathrm{~min}$ $(5.9 \pm 0.5, \mathrm{G}-\mathrm{N} ; 5.8 \pm 0.6, \mathrm{G}-\mathrm{E} ; \mathrm{ng} /$ plate $)$ and $30 \mathrm{~min}(7.9 \pm 0.3$, G-N; 8.2 $\pm 0.7, \mathrm{G}-\mathrm{E} ; \mathrm{ng} /$ plate).

In subsequent studies, these preliminary observations were examined in more detail. The time course of release of total ${ }^{14} \mathrm{C}$ radioactivity in response to $1 \mu \mathrm{M}$ A23187 is shown in Fig. 1. The rates of net release were similar at both glucose concentrations for $10 \mathrm{~min}$. Thereafter, release continued at an approximately linear rate from $\mathrm{G}-\mathrm{N}$ cells but the net release from G-E cells was significantly depressed $(P<0.05)$.

The observed effects of elevated glucose on ionophore-induced release of radioactivity were both sugar specific and not due to increased osmolarity. Equiosmolar concentrations of mannose, mannitol, sucrose, or L-glucose were substituted for the additional glucose in the conditioning and stimulation regimens. The release of radioactivity under these conditions was identical to the release from G-N cells (Fig. 2). The effect of increased glucose concentration on the ionophore-induced release of radioactivity could be induced by a 2 -h incubation with increased glucose, and reversed within $2 \mathrm{~h}$ by incubating G-E cells in $5.2 \mathrm{mM}$ glucose (data not shown).

Resolution of the $\left[{ }^{14} \mathrm{C}\right]$ eicosanoid classes released into the medium in response to $1 \mu \mathrm{M} \mathrm{A23187}$ is shown in Fig. 3. The higher glucose concentration did not alter the time course or magnitude of release of cyclooxygenase products. In data not shown, no differences were observed in the release of individual ${ }^{14} \mathrm{C}$-labeled prostaglandins. This data is consistent with our preliminary data on 6-keto-PGF ${ }_{1 \alpha}$ measured by RIA. In contrast, striking disparities were noted in the appearance of ra-

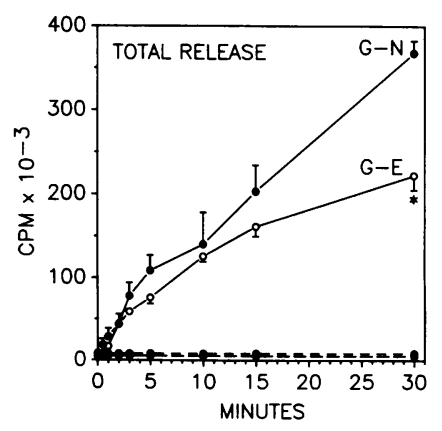

Figure 1. Effect of elevated glucose on the release of ${ }^{14} \mathrm{C}$ radioactivity from stimulated endothelial cells. Cultured porcine aortic endothelial cells were conditioned in two concentrations of glucose $(5.2$ $\mathrm{mM}$, normal glucose, G-N; $15.6 \mathrm{mM}$, elevated glucose, G-E). Confluent cultures (6.5 $\times 10^{6}$ cells $/ 100 \mathrm{~mm}$ plate) were prelabeled with $1 \mu \mathrm{M}$ $\left[{ }^{14} \mathrm{C}\right]$ arachidonic acid/1 $\mu \mathrm{M}$ bovine serum albumin in $10 \%$ FCS for $24 \mathrm{~h}$. The net uptake of [ $\left.{ }^{14} \mathrm{C}\right]-$ arachidonic acid was $1117 \pm 41 \times 10^{3} \mathrm{cpm}, \mathrm{G}-\mathrm{N}$ cells; $1117 \pm 49 \times 10^{3}$ $\mathrm{cpm}$, G-E cells. After rinsing, cells were stimulated with $1 \mathrm{uM}$ A23187 or vehicle (broken lines) for the times indicated. Data are expressed as the mean $\pm \mathrm{SE}$ of three experiments performed in duplicate. ${ }^{*} P<0.05$ as determined by the paired $t$ test. 


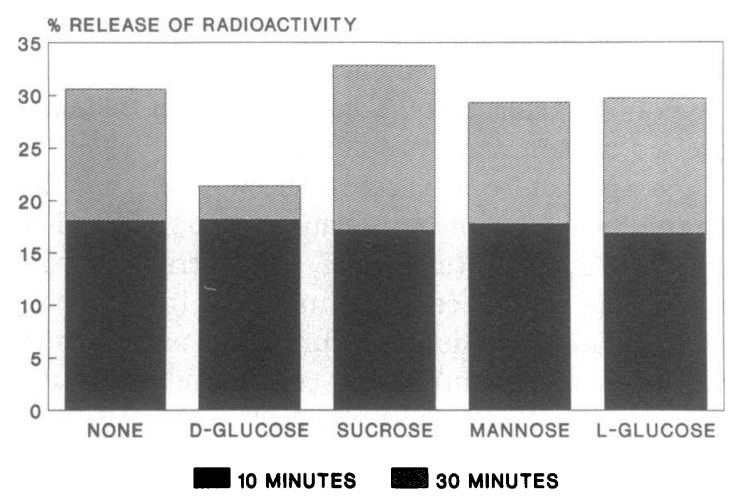

Figure 2. Specificity for glucose in the pertubation of eicosanoid release. Cultured porcine aortic endothelial cells were conditioned through two passages and labeled with $\left[{ }^{14} \mathrm{C}\right]$ arachidonic acid in medium containing a normal glucose concentration $(5.2 \mathrm{mM}, \mathrm{G}-\mathrm{N})$ or with an additional $10.4 \mathrm{mM}$ of the sugars indicated. The confluent cells were then stimulated with $1 \mu \mathrm{M}$ A23187. Details of the conditioning, labeling, and stimulation may be found in Methods and the legend to Fig. 1. The data indicate the percentage of total cellular ${ }^{14} \mathrm{C}$ radioactivity released into the medium upon stimulation with the ionophore A23187. Values represent the mean of two experiments each performed in triplicate. There was $<10 \%$ difference in the data obtained from each experiment.

diolabeled lipoxygenase-derived products and free $\left[{ }^{14} \mathrm{C}\right]-$ arachidonic acid. The net rates of release of lipoxygenase-derived products diverged after $10 \mathrm{~min}$ and were significantly different at $30 \mathrm{~min}$. The net release of free $\left[{ }^{14} \mathrm{C}\right]$ arachidonic acid in the medium increased at a near-linear rate throughout the time course for G-N cells $\left(\sim 9.1 \times 10^{3} \mathrm{cpm} / \mathrm{min}\right)$. G-E
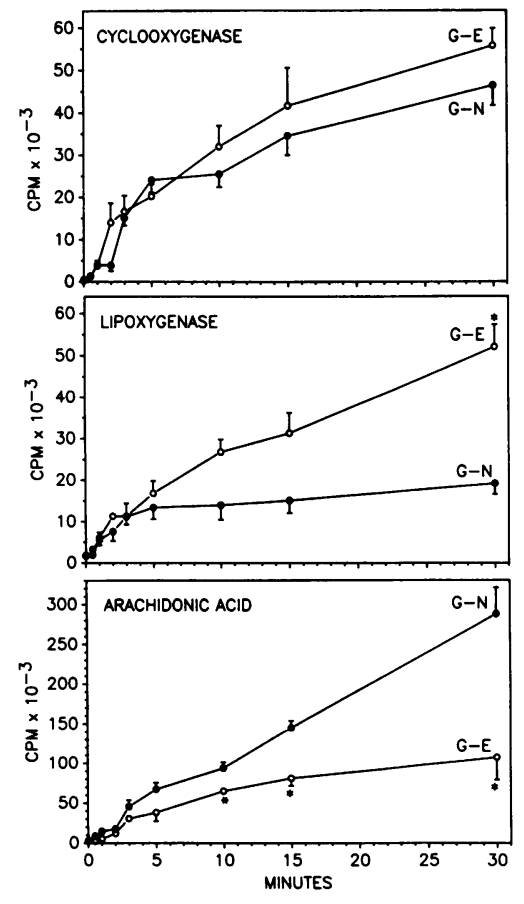

Figure 3. Effect of glucose concentration on the release of ${ }^{14} \mathrm{C}$-labeled eicosanoids from stimulated endothelial cells. Cultured porcine aortic endothelial cells $\left(6.5 \times 10^{6}\right.$ cells $/ 100$ mm plate) were conditioned in $5.2 \mathrm{mM}$ glucose (G-N) or $15.6 \mathrm{mM}$ glucose (G-E) and prelabeled with $1 \mu \mathrm{M}\left[{ }^{14} \mathrm{C}\right]-$ arachidonic acid/1 $\mu \mathrm{M}$ bovine serum albumin for $24 \mathrm{~h}$ (for further details see Methods and legend to Fig. 1). After rinsing, the cells were stimulated with $1 \mu \mathrm{M}$ A23187 for the times indicated. The medium was extracted and eicosanoids were resolved by reverse-phase HPLC. Data are expressed as the mean \pm SE of three experiments performed in duplicate. ${ }^{*} P<0.05$ as determined by the paired $t$ test. cells released $\left[{ }^{14} \mathrm{C}\right]$ arachidonic acid at a slower rate $(\sim 8.2$ $\times 10^{3} \mathrm{cpm} / \mathrm{min}$ ) for the first $5 \mathrm{~min}$ and $\sim 2.7 \times 10^{3} \mathrm{cpm} / \mathrm{min}$ thereafter.

The time course of release of the two major lipoxygenase products, 5- and 15-HETE, is illustrated in Fig. 4. At all time points, the release of 5-HETE from G-E cells was greater than from G-N cells, although the absolute difference was not statistically significant. The initial release of 15 -HETE was similar from both groups of cells, but G-E cells released more 15-HETE at later time points (a significant increment of $129 \%$ at $30 \mathrm{~min}$ ).

In experiments not using radiolabeled arachidonic acid, the release of 15-HETE, 5-HETE, and 6-keto-PGF ${ }_{1 \alpha}$ was measured directly by RIA (Tables I-III). These mass determinations confirmed that between 10 and 30 min G-E cells released greater amounts of 5- and 15-HETE, but not 6-keto-PGF ${ }_{1 \alpha}$. Although the various agonists resulted in different absolute amounts of eicosanoids released, significant increases were observed for 15-HETE, independent of the agonist used. A significant increase in the release of 5-HETE by G-E cells was noted after stimulation with the ionophore. Elevation of the glucose concentration was without effect on agonist-induced release of 6-keto-PGF $1 \alpha$.

In other experiments, confluent cultures were incubated with $1 \mu \mathrm{M}$ unlabeled arachidonic acid (NuChek Prep., Elysian, MN) bound to $1 \mu \mathrm{M}$ BSA in complete medium for $24 \mathrm{~h}$ before stimulation. Levels of immunoreactive 15-HETE, 5-HETE, and 6-keto-PGF $F_{1 \alpha}$ measured under these conditions were essentially identical to those measured in experiments without exogenous arachidonic acid addition (data not shown).

\section{Discussion}

Our experiments were undertaken to determine if increased glucose concentrations influenced the rate and pattern of eicosanoid elaboration by stimulated endothelial cells. The preliminary data presented in the text and the more detailed data in Fig. 1 demonstrate that elevated glucose had no effect on the initial release of total ${ }^{14} \mathrm{C}$ radioactivity from cells labeled with

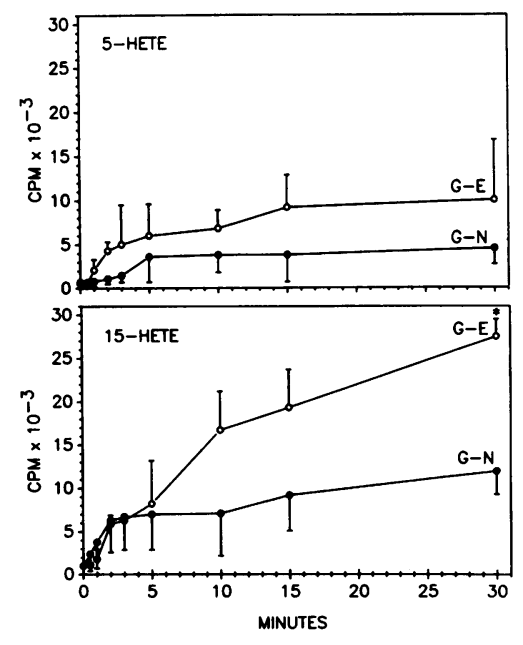

Figure 4. Effect of elevated glucose on the release of ${ }^{14} \mathrm{C}$-labeled HETEs from stimulated endothelial cells. Cultured porcine aortic endothelial cells $(6.5$ $\times 10^{6}$ cells $/ 100 \mathrm{~mm}$ plate) were conditioned in two concentrations of glucose and labeled with $1 \mu \mathrm{M}\left[{ }^{14} \mathrm{C}\right]-$ arachidonic acid/1 $\mu \mathrm{M}$ bovine serum albumin for $24 \mathrm{~h}$ (for further details see methods and legend to Fig. 1). After rinsing, the cells were stimulated with $1 \mu \mathrm{M}$ A23187 for the times indicated. The medium was extracted and eicosanoids were resolved by reverse-phase HPLC. Data are presented as the mean $\pm \mathrm{SE}$ of three experiments performed in duplicate. ${ }^{*} P<$ 0.05 as determined by the paired $t$ test. 
Table I. Effect of Glucose Concentration on the Release of 15-HETE from Stimulated Endothelial Cells

\begin{tabular}{|c|c|c|c|c|c|c|}
\hline \multirow[b]{2}{*}{ Time } & \multicolumn{2}{|c|}{ A23187 } & \multicolumn{2}{|c|}{$\begin{array}{c}\text { Bradykinin } \\
\text { 15-HETE (ng/plate) }\end{array}$} & \multicolumn{2}{|c|}{ Thrombin } \\
\hline & G-N & G-E & G-N & G-E & G-N & G-E \\
\hline \multicolumn{7}{|l|}{$\min$} \\
\hline 0 & $<2.0$ & $<2.0$ & $<2.0$ & $<2.0$ & $<2.0$ & $<2.0$ \\
\hline 10 & $82.8 \pm 2.0$ & $89.1 \pm 4.9$ & $16.3 \pm 2.0$ & $17.2 \pm 2.4$ & $2.2 \pm 1.1$ & $4.9 \pm 2.8$ \\
\hline 30 & $99.0 \pm 3.1$ & $138 \pm 6.1^{*}$ & $18.7 \pm 1.0$ & $28.3 \pm 1.7^{\ddagger}$ & $5.0 \pm 1.2$ & $11.2 \pm 1.3^{\ddagger}$ \\
\hline
\end{tabular}

Porcine aortic endothelial cells in culture were conditioned in two concentrations of glucose (for further details see Methods and the legend to Fig. 1). Confluent, conditioned cultures were rinsed and treated with A23187 (1 $\mu \mathrm{M})$, bradykinin $(1 \mu \mathrm{M})$ or thrombin $(2.5 \mathrm{U} / \mathrm{ml})$ for the times indicated. 15-HETE was measured by RIA. Data are presented as the mean \pm SE of five experiments performed in duplicate.

${ }^{*} P<0.01{ }^{\ddagger} P<0.05$ (paired $t$ test).

$\left[{ }^{14} \mathrm{C}\right]$ arachidonic acid. Similarly, elevated glucose did not alter prostaglandin production at any time point during stimulation. Our data confirm the findings of others $(14,15)$ who have shown that exposure of cultured endothelial cells to glucose concentrations as high as $22.4 \mathrm{mM}$ did not alter 6-keto-PGF ${ }_{10}$ production. However, the time-dependent suppression of total ${ }^{14} \mathrm{C}$ radioactivity released from prelabeled cells has not been previously documented.

The influence of elevated glucose on ionophore-induced eicosanoid release is apparently specific for the D-isomer of glucose as illustrated in Fig. 2. Neither sucrose, nor the optical isomer, L-glucose, is metabolized by endothelial cells, but each would increase the osmolarity of the medium. L-glucose could potentially mediate any effects due to nonenzymatic glycosylation of proteins. However, diminished release of eicosanoids was not observed for these sugars eliminating hyperosmolarity as well as protein glycosylation as potential causes of the decreased release. D-mannose, a geometric isomer of glucose, can enter the glycolytic pathway. Since mannose was without effect, intermediary metabolites of glycolysis would probably also be without effect.

Table II. Effect of Glucose Concentration on the Release of 5-HETE from Stimulated Endothelial Cells

\begin{tabular}{|c|c|c|c|c|c|c|}
\hline \multirow[b]{3}{*}{ Time } & \multicolumn{2}{|c|}{ A23187 } & \multicolumn{2}{|c|}{ Bradykinin } & \multicolumn{2}{|c|}{ Thrombin } \\
\hline & \multicolumn{6}{|c|}{ 5-HETE (ng/plate) } \\
\hline & G-N & G-E & G-N & G-E & G-N & G-E \\
\hline $\min$ & & & & & & \\
\hline 0 & $3.1 \pm 2.0$ & $<2.0$ & $<2.0$ & $<2.0$ & $<2.0$ & $<2.0$ \\
\hline 10 & $12.5 \pm 2.0$ & $13.5 \pm 2.1$ & $4.5 \pm 1.5$ & $7.6 \pm 2.0$ & $4.6 \pm 1.4$ & $4.6 \pm 1.1$ \\
\hline 30 & $19.1 \pm 2.1$ & $28.8 \pm 2.5^{*}$ & $9.6 \pm 4.5$ & $9.5 \pm 4.4$ & $6.0 \pm 1.2$ & $5.8 \pm 1.3$ \\
\hline
\end{tabular}

Porcine aortic endothelial cells in culture were conditioned in two concentrations of glucose stimulated with A23187 $(1 \mu \mathrm{M})$, bradykinin $(1 \mu \mathrm{M})$ or thrombin $(2.5 \mathrm{U} / \mathrm{ml})$ and 5-HETE was measured by RIA (see legend to Table I). Data are presented as the mean \pm SE of 5 experiments performed in duplicate.

${ }^{*} P<0.05$ (paired $t$ test).
Table III. Effect of Glucose Concentration on the Release of 6-keto-PGF $F_{1 \alpha}$ from Stimulated Endothelial Cells

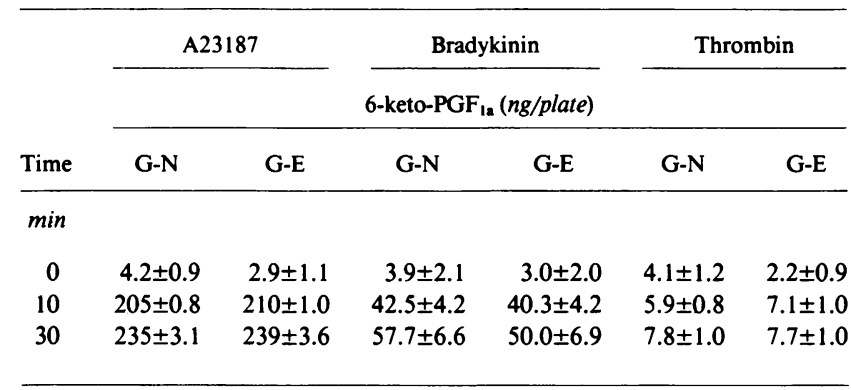

Porcine aortic endothelial cells in culture were conditioned in two concentrations of glucose, stimulated with the ionophore A23187 $(1 \mu \mathrm{M})$, bradykinin (1 $\mu \mathrm{M})$, or thrombin $(2.5 \mathrm{U} / \mathrm{ml})$ and 6-keto-PGF ${ }_{1 \alpha}$ was measured by RIA (see legend to Table I). Data are presented as the mean $\pm \mathrm{SE}$ of five experiments performed in duplicate.

The data illustrated in Figs. 3 and 4 demonstrate that increased glucose concentration in the medium exerted a disparate effect on the release of free $\left[{ }^{14} \mathrm{C}\right]$ arachidonic acid and HETEs. The data shown in Fig. 4 and Tables I and II demonstrate that porcine endothelial cells produce both 5- and 15 HETE, as has been previously indicated for human umbilical endothelial cells $(5,6)$. The decreased net release of arachidonic acid was evident after $5 \mathrm{~min}$ and was striking after 30 min. In sharp contrast, increasing the glucose concentration in the medium stimulated the release of both 5- and 15-HETE. The absolute magnitude of the suppression of $\left[{ }^{14} \mathrm{C}\right]$ arachidonic acid release overshadowed the enhanced HETE production, resulting in the net decrease in total ${ }^{14} \mathrm{C}$ radioactivity release from G-E cells. The observation that increased glucose concentration increased ionophore-induced release of 5- and 15HETE was confirmed in both the radiolabel experiments and those measuring mass by RIA. The magnitude of the increased HETE measured was not identical for the two techniques. However, since the specific activity of $\left[{ }^{14} \mathrm{C}\right]$ arachidonic acid in the phospholipid precursor pools was unknown, absolute differences in the magnitude of the effect between mass measurements and net release of radioactivity is not surprising.

Glucose may exert its effects on free arachidonic acid and HETE release by independent mechanisms. Alternatively, it is possible that the enhanced production of HETE may itself exert an inhibitory effect on phospholipase activity. Lipoxygenase-derived products have been demonstrated to exhibit remarkably diverse effects on phospholipase activity in various cell types. Thus, studies from this laboratory have demonstrated that 15-HPETE, but not 15-HETE stimulates the net release of arachidonic acid from calf aortic endothelial cells (16). In human neutrophils, 5-HPETE and 5-HETE augmented phospholipase $A_{2}$ activity in response to ionophore, but 8-HETE and 15-HETE were ineffective (17). In contrast, Chang and associates (18) have shown that 5-HETE, 12HETE, and 15-HETE all inhibited platelet phospholipase $A_{2}$ activity. These studies suggest that the decreased release of arachidonic acid under G-E conditions may be mediated by increased HETE generation.

Sagone et al. (19) have shown glucose to be a weak hydroxyl radical $\left(\mathrm{OH}^{\circ}\right)$ scavenger in biological systems. These investigators associated the $\mathrm{OH}^{*}$ scavenging capacity of glucose 
with its ability to increase the synthesis of HETE and HPETE. Hydroxyl radicals generated during lipoxygenase activity have been suggested to inhibit lipoxygenase itself (20). Elevation of the glucose concentration had no effect on the release of cyclooxygenase products. The observation that $\mathrm{OH}^{*}$ is not generated during cyclooxygenase activity $(19,20)$ is consistent with the lack of effect of increased glucose concentration on the elaboration of cyclooxygenase products. Indeed, the time course of prostaglandin production we observed was very rapid relative to lipoxygenase-product release. It is possible that cyclooxygenase activity would already itself be self-limited before augmented lipoxygenase activity could result in the accumulation of inhibitory concentrations of metabolites.

The decreased amounts of $\left[{ }^{14} \mathrm{C}\right]$ arachidonic acid in the medium of stimulated G-E cells at later time points could be due to increased reacylation of arachidonic acid in the presence of increased glucose, which could be acting independently or in concert with a phospholipase inhibitory mechanism. Laychock (21) reported that $25 \mathrm{mM}$ glucose stimulated the incorporation of $\left[{ }^{14} \mathrm{C}\right]$ arachidonic acid into phosphatidylinositol and phosphatidylcholine of pancreatic islet cells. In other experiments it was observed that glucose activated a crude phospholipase $\mathrm{A}_{2}$ preparation from islet cells, suggesting a direct role of glucose in the acylation/reacylation of arachidonic acid (22). Recently, Goppelt-Struebe et al. (23) reported that during activation of rat peritoneal macrophages concomitant reacylation reactions could modulate eicosanoid release. This group suggested that merthiolate could effectively inhibit the reacylation mechanism in a time- and dose-dependent manner. We are currently evaluating the utility of such agents in delineating the pathways responsible for the net decrease in free arachidonic acid released from endothelial cells in the presence of elevated glucose.

The physiological significance of the inhibitory effect of glucose on mobilization of arachidonic acid is not clear. However, it is of interest that glucose also inhibits the closure of the rostral neural tube in mouse embryo cultures and that this teratogenic effect can be reversed by the addition of arachidonic acid to the medium (24). Furthermore, the administration of arachidonic acid to pregnant diabetic rats prevented the fetal neural tube defects found in untreated controls. These data suggest that hyperglycemia-induced teratogenesis may be mediated by a functional deficiency of arachidonic acid (24).

Our observation of enhanced 15-HETE synthesis by endothelial cells exposed to increase glucose is consistent with that of Setty and Stuart (7). These investigators found that segments of human umbilical arteries obtained from infants of diabetic mothers produced significantly more 15-HETE than similar vascular segments from infants of normal mothers.

The current data do not provide a direct explanation for the observed effects of increased glucose on endothelial eicosanoid metabolism. Whatever mechanism is operative, it must be induced within $2 \mathrm{~h}$ of exposure to elevated glucose and reversed within $2 \mathrm{~h}$ of restoration of normal glucose levels. Short-term changes in the polyol pathway of glucose metabolism or the rapid glycosylation of regulatory enzymes are attractive candidates, but how such changes are reflected in either phospholipase or lipoxygenase activities remains to be explained. The alteration of receptors is a less appealing explanation since ionophore-induced, as well as bradykinin-induced, eicosanoid metabolism are altered by high glucose. These possibilities are under investigation in our laboratories.
Such studies may provide new information on sites of regulation of arachidonic acid metabolism and their perturbation in diabetes mellitus.

\section{Acknowledgments}

The authors gratefully acknowledge the assistance of Charlene Guertin in the preparation of this manuscript, and the technical assistance of Genevieve Neal.

These studies were supported by grants from the Medical Research Service of the Veterans Administration and the National Institute of Health (HL-26895 and DK-39624).

\section{References}

1. Colwell, J. A., P. I. Winocour, and P. V. Halushka. 1983. Do platelets have anything to do with diabetic microvascular disease? Diabetes. 32(Suppl. 2):14-19.

2. Halushka, P. V., R. Mayfield, and J. A. Colwell. 1985. Insulin and arachidonic acid metabolism in diabetes mellitus. Metab. Clin. Exp. 34(Suppl. 1):32-36.

3. Hamberg, M., and R. Samuelson. 1974. Prostaglandin endoperoxides. Novel transformations of arachidonic acid in human platelets. Proc. Natl. Acad. Sci. USA. 71:3400-3404.

4. Siegel, M. I., R. T. McConnell, N. A. Porter, and P. Cuatrecasas. 1980. Arachidonate metabolism via lipoxygenase and $12 \mathrm{~L}$-hydroperoxy-5,8,10,14-icosatetraenoic acid peroxidase sensitive to anti-inflammatory drugs. Proc. Natl. Acad. Sci. USA. 77:308-312.

5. Hopkins, N. K., T. D. Oglesby, G. L. Bundy, and R. R. Gorman. 1984. Biosynthesis and metabolism of 15-hydroperoxyeicosatetraenoic acid by human umbilical vein cells. J. Biol. Chem. 259:1404814053.

6. Gorman, R. R., T. D. Oglesby, G. L. Bundy, and N. K. Hopkins. 1985. Evidence for 15-HETE synthesis by human umbilical vein endothelial cells. Circulation. 72:708-712.

7. Setty, B. N. Y., and M. J. Stuart. 1986. 15-hydroxy-5,8,11,13-eicosatetraenoic acid inhibits human vascular cyclooxygenase. Potential role in diabetic vascular disease. J. Clin. Invest. 77:202-217.

8. Mayer, B., R. Moser, H. Gleispach, and W. R. Kukocetz. 1986. Possible inhibitory functions of endogenous 15-hydroperoxyeicosatetraenoic acid on prostacyclin formation in bovine aortic endothelial cells. Biochim. Biophys. Acta. 875:641-653.

9. Turk, J., J. R. Colca, N. Kotagal, and M. L. McDaniel. 1984. Arachidonic acid metabolism in isolated pancreatic islets: The effects of glucose and of inhibitors of arachidonate metabolism on insulin secretion and metabolite synthesis. Biochim. Biophys. Acta. 794:125136.

10. Metz, S. A. 1985. Glucose increases the synthesis of lipoxygenase-mediated metabolites of arachidonic acid in intact rat islets. Proc. Natl. Acad. Sci. USA. 82:198-202.

11. Wey, H. E., J. A. Jakubowski, and D. Deykin. 1986. Incorporation and redistribution of arachidonic acid in diacyl and ether phospholipids of bovine aortic endothelial cells. Biochim. Biophys. Acta. 878:380-386.

12. Brown, M. L., J. A. Jakubowski, L. L. Leventis, and D. Deykin. 1987. Ionophore-induced metabolism of phospholipids and eicosanoid production in porcine aortic endothelial cells. Selective release of arachidonic acid from diacyl and ether-linked phospholipids. Biochim. Biophys. Acta. 921:159-166.

13. Jakubowski, J. A., M. J. Stampfer, R. Vaillancourt, and D. Deykin. 1985. Cumulative antiplatelet effects of low-dose enteric coated aspirin. Br. J. Haematol. 60:635-642.

14. Aanderud, S., S. A. Krane, and A. Nordoy. 1985. Influence of glucose, insulin and sera of diabetic patients on prostacyclin synthesis in vitro in cultured human endothelial cells. Diabetologia. 28:641644.

15. Weimann, B. J., E. Lorch, and H. R. Baumgartner. 1984. High 
glucose concentrations do not influence replication and prostacyclin release of human endothelial cells. Diabetologia. 27:62-63 (Letter).

16. Hong, S. L., T. Carty, and D. Deykin. 1980. Tranylcypromine and 15-hydroperoxyarachidonate affect arachidonic acid release in addition to inhibition of prostacyclin synthesis in calf aortic endothelial cells. J. Biol. Chem. 255:9538-9540.

17. Billah, M. M., R. W. Bryant, and M. L. Siegal. 1985. Lipoxygenase products of arachidonic acid modulate biosynthesis of plateletactivating-factor (1-0-alkyl-2-acetyl-sn-glycero-3-phosphocholine) by human neutrophils via phospholipase $\mathrm{A}_{2}$. J. Biol. Chem. 260:68996906.

18. Chang, J., E. Blazek, A. F. Kreft, and A. J. Lewis. 1985. Inhibition of platelet and neutrophil phospholipase $A_{2}$ by hydroxyeicosatetraenoic acids (HETES). A novel pharmacological mechanism for regulating free fatty acid release. Biochem. Pharmacol. 34:1571-1575.

19. Sagone, A. L., Jr., J. Greenwald, E. H. Kraut, J. Bianchine, and D. Singh. 1983. Glucose: A role as a free radical scavenger in biological systems. J. Lab. Clin. Med. 101:97-104.
20. Singh, D. J., J. Greenwald, E. N. Metz, J. Bianchine, and A. L. Sagone, Jr. 1981. Evidence for the generation of hydroxy radical during arachidonic acid metabolism by human platelets. Am. J. Hematol. 11:233-240.

21. Laychock, S. G. 1983. Fatty acid incorporation into phospholipids of isolated pancreatic islet of the rat. Relationship to insulin release. Diabetes. 32:6-13.

22. Laychock, S. G. 1982. Phospholipase $A_{2}$ activity in pancreatic islets is calcium-dependent and stimulated by glucose. Cell Calcium. 3:43-54.

23. Goppelt-Struebe, M., C.-F. Koerner, G. Hausmann, D. Gemsa, and K. Resch. 1986. Control of prostanoid synthesis: Role of reincorporation of released precursor fatty acid. Prostaglandins. 32:373-385.

24. Goldman, A. S., L. Baker, R. Piddington, B. Marx, R. Herold, and J. Egler. 1985. Hyperglycemia-induced teratogenesis is mediated by a functional deficiency of arachidonic acid. Proc. Natl. Acad. Sci. USA. 82:8227-8231. 